\title{
Roles of HTLV-1 basic Zip Factor (HBZ) in Viral Chronicity and Leukemic Transformation. Potential New Therapeutic Approaches to Prevent and Treat HTLV-1-Related Diseases
}

\author{
Jean-Michel Mesnard ${ }^{1}$, Benoit Barbeau ${ }^{2}$, Raymond Césaire ${ }^{3}$ and Jean-Marie Péloponèse ${ }^{1, *}$ \\ Received: 15 October 2015; Accepted: 1 December 2015; Published: 9 December 2015 \\ Academic Editor: Louis M. Mansky \\ 1 CPBS, CNRS FRE3689, Université Montpellier, 34293 Montpellier, France; jean-michel.mesnard@cpbs.cnrs.fr \\ 2 Département des Sciences Biologiques, and Centre de Recherche BioMed Université du Québec à Montréal, \\ Montréal, QC H2X 3X8, Canada; barbeau.benoit@uqam.ca \\ 3 Laboratoire de Virologie-EA4537, Centre Hospitalier et Universitaire de Martinique, Fort de France, \\ Martinique; Raymond.Cesaire@chu-fortdefrance.fr \\ * Correspondence: jean-marie.peloponese@cpbs.cnrs.fr; Tel.: +33-434-359-440; Fax: +33-467-604-420
}

\begin{abstract}
More than thirty years have passed since human T-cell leukemia virus type 1 (HTLV-1) was described as the first retrovirus to be the causative agent of a human cancer, adult T-cell leukemia (ATL), but the precise mechanism behind HTLV-1 pathogenesis still remains elusive. For more than two decades, the transforming ability of HTLV-1 has been exclusively associated to the viral transactivator Tax. Thirteen year ago, we first reported that the minus strand of HTLV-1 encoded for a basic Zip factor factor (HBZ), and since then several teams have underscored the importance of this antisense viral protein for the maintenance of a chronic infection and the proliferation of infected cells. More recently, we as well as others have demonstrated that HBZ has the potential to transform cells both in vitro and in vivo. In this review, we focus on the latest progress in our understanding of HBZ functions in chronicity and cellular transformation. We will discuss the involvement of this paradigm shift of HTLV-1 research on new therapeutic approaches to treat HTLV-1-related human diseases.
\end{abstract}

Keywords: human T-cell leukemia virus type 1; adult T-cell leukemia; HTLV-1 bZip Factor; Valproate

\section{Introduction}

Thirty years ago, human T-cell leukemia virus type 1 (HTLV-1) was the first human retrovirus to be identified and is now known as the causative agent of a very aggressive form of leukemia termed adult T-cell leukemia (ATL). It was isolated in the early 1980s, first in the United States [1] and then in Japan [2,3]. Currently, HTLV-1 infects approximately 15 million individuals worldwide [4]. HTLV-1 is the etiological agent of both ATL and a slowly progressive neurologic disorder called HTLV-1-associated myelopathy/tropical spastic paraparesis (HAM/TSP). [5,6]. The role of HTLV-1 in $\mathrm{HAM} / \mathrm{TSP}$ will not be discussed here. Below, we summarize and update insights relevant to human leukemogenesis induced by HTLV-1.

\section{HTLV-1 Infectivity and Spread in vivo}

Like any animal retrovirus, the HTLV-1 proviral genome encodes for the structural genes, gag, pol and $e n v$, and is bordered by two long terminal repeat sequences (LTR) [7]. The $5^{\prime}$ LTR serves as the main promoter for viral transcription. HTLV-1 is defined as a complex retrovirus because its genome also contains a region termed the $\mathrm{pX}$ region, which it located between the env gene and the $3^{\prime}$-LTR and 
contains genes encoding regulatory viral factors, Tax, Rex, $\mathrm{p} 12^{\mathrm{I}}, \mathrm{p} 13^{\mathrm{II}}, \mathrm{p} 30^{\mathrm{II}}$ and $\mathrm{p} 21^{\mathrm{I}}$. Furthermore, the minus strand of $\mathrm{pX}$ has been found to produce an antisense transcript, encoding HBZ [8-11] (Figure 1).

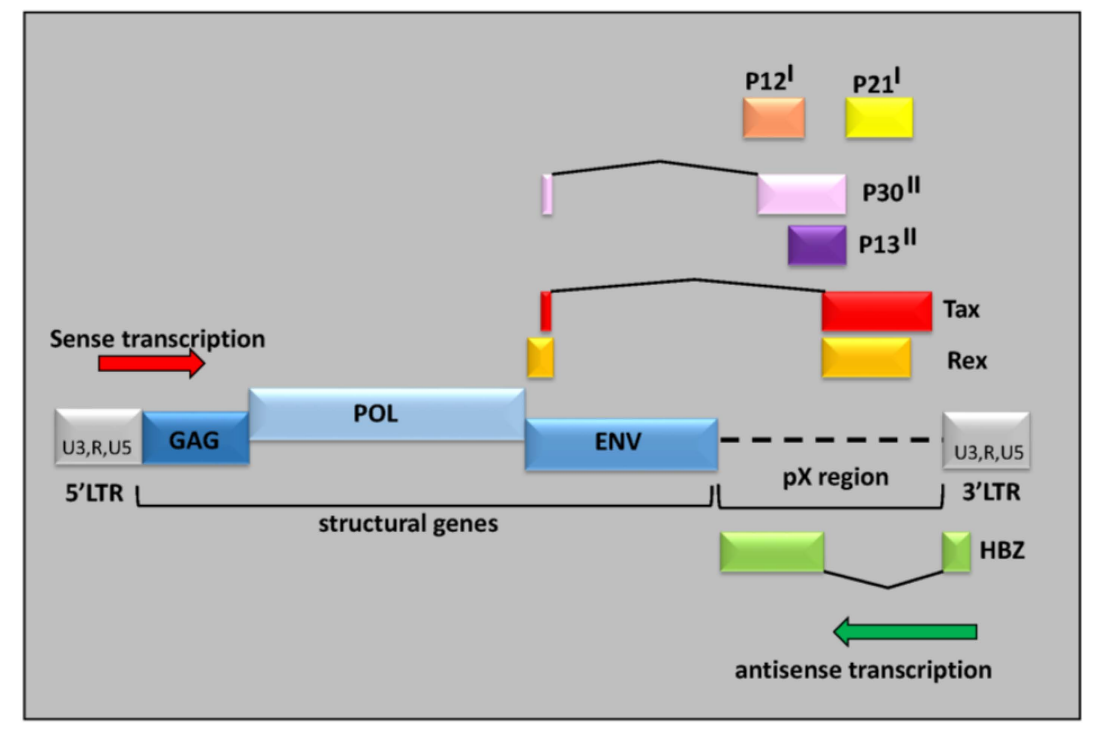

Figure 1. Structure of the HTLV-1 provirus: The human T-cell leukemia virus type 1 (HTLV-1) genome encodes for three structural proteins, Gag, Pol, and Env, and complex regulatory proteins such as Tax, which not only activates viral replication, but also induces the expression of several cellular genes. The in vivo expression of these viral proteins is suppressed by cytotoxic T lymphocyte (CTL) activity. HTLV-1 basic Zip factor (HBZ), produced by a minus-strand mRNA, likely plays a role in viral replication and T-cell proliferation as it is steadily expressed in most HTLV-1-infected cells and primary adult T-cell leukemia (ATL) cells, whereas Tax is not.

In vitro, HTLV-1 can infect a large variety of cells, including T- and B-cells, fibroblasts, macrophages, and dendritic cells [12]. These observations indicate that the receptor is common and expressed on a large number of cells. Studies show that glucose transporter 1 (Glut-1), heparan sulfate proteoglycans (HSPGs), and neuropilin-1 (NRP-1) are three proteins involved in the mechanism of HTLV-1 entry [13-15]. The current view on the entry event of HTLV-1 suggests that the virus first interacts with HSPG and then forms complexes with NRP-1 followed by an association with Glut-1 at the cell surface before final membrane fusion and entry into the cell. However, how these factors cooperate with each other requires further study. It is interesting to note that, despite the ubiquitous distribution of these membrane proteins, in vivo, the HTLV-1 provirus is mainly detected in CD4+ and in CD8+ T-cells [16]. There is nonetheless evidence that cellular receptors play an important role in determining the cellular tropism of HTLV-1 [17]. Thus, the differential outcome of HTLV-1 on CD4+ and CD8+ cell proliferation may be more important in dictating the apparent specificity for CD4+ cells than is receptor-binding and differences related to cellular entry [18].

In vivo, HTLV-1 is primarily transmitted by cell-to-cell contact, and not by cell-free virions [19]. Upon contact with an uninfected cell, HTLV-1-infected cells will transiently express high levels of Tax and intercellular adhesion molecule-1 (ICAM-1) to form a virological synapse [20] or a viral biofilm [21]. Enveloped viral particles can transfer through this synapse, thus propagating infection [22]. Recently, it has been reported that HTLV-1 cell-to-cell transmission is ten thousand times more efficient than cell-free infection, while, in comparison, similar experiments have shown that for human immunodeficiency virus type 1 (HIV-1) infection, this difference is only twofold [23]. However, the importance of in vivo cell-to-cell spread is tempered by findings that the administration of reverse transcriptase inhibitors (RTI) to HTLV-1-infected patients with HAM/TSP does not markedly influence the provirus load [24], and that RTI treatment immediately after HTLV-1 infection in vivo does not change subsequent proviral load. Thus, viral replication itself does not appear to be critical for 
the maintenance of persistent infection; rather, the proliferation of HTLV-1-infected cells seems to determine viral burden at the carrier state. In this regard, the viral strategy to increase the number of infected cells by promoting cellular proliferation is meaningful. Indeed, a long-standing observation is that HTLV-1 induces clonal proliferation of infected cells in vivo $[18,25,26]$.

\section{HTLV-1, Chronicity and Host Immune Response}

In order to induce chronic infection, viruses need to establish an equilibrium between viral virulence and the host immunity [27]. Accordingly, human retroviruses, such as HTLV-1, have evolved several strategies to control the host immune system and temper viral replication, one of which is to directly deregulate the major histocompatibility complex (MHC) [27]. The function of MHC molecules is to bind peptide fragments derived from pathogens and display them on the cell surface for recognition by the appropriate T-cells. The consequences are often deleterious to the pathogen-virus-infected cells are killed and B-cells are activated to produce antibodies that eliminate or neutralize extracellular pathogens. Thus, there is a strong selective pressure in favor of any virus that has evolved mechanism allowing them to escape presentation of its antigens by MHC molecules. In its $\mathrm{pX}$ region, HTLV-1 encodes an accessory protein, $\mathrm{p} 12$ that interacts with MHC class I heavy chains, and leads to its degradation by the proteasome [28]. In HTLV-1-infected host, chronically activated cytotoxic T lymphocyte (CTL) response [29-31] and high titer of anti-HTLV-1 antibodies, mostly directed against the Tax protein [32-34], strongly support the idea that Tax is the main immunogenic target. Indeed, in vivo depletion of Tax-expressing CD4+ T-cells leads to moderate HTLV-1 replication [35]. CD8+ CTLs are in part responsible for this phenomenon because their depletion enhances Tax expression in vivo [35]. Furthermore, when a histone deacetylase inhibitor, valproate, was used to reactivate tax transcription in HTLV-infected host, their proviral load became reduced [36-38]. A similar observation of valproate-induced reduction of Simian T-Cell Leukemia Virus (STLV) proviral load has been also reported in a simian model [39]. Thus host's CTL response targets Tax-expressing cells, thereby reducing the number of infected cells in vivo. In fact, the HTLV-1 proviral load appears to be maintained, when an equilibrium is established with the immune response, allowing the maintenance and the proliferation of HTLV-1-infected cells [40]. While Tax is frequently targeted by CTL in HTLV-1 infection [32-34], the frequency of HBZ-specific CTL is low and could only be detected in $25 \%-40 \%$ of infected individuals [41,42]. However, in a systematic study, MacNamara et al. [42] showed that protective alleles $A^{*} 0201$ and $C^{*} 0801$ bound HBZ-derived peptides with significantly higher affinity in comparison to alleles which were associated with disease progression $\left(B^{*} 5401\right)$. However, further analyses demonstrated that asymptomatic carriers ACs had human leukocyte antigen (HLA) alleles which bound HBZ peptides significantly more strongly than patients with HAM/TSP, and that this difference in binding was not simply attributable to $A^{*} 0201, C^{*} 0801$, and $B^{*} 5401[41,42]$.

In order to escape the host immune response, a proportion of cells that express Tax must subsequently shut down its expression. Recently, various molecular mechanisms accounting for suppression of Tax expression have been suggested, implicating viral-Rex [43], the $\mathrm{pX}$ protein $\mathrm{p} 30$ II [44] and HBZ [8] — and cellular proteins—histone deacetylases [45] and GLI-2/THP [46]. In each study, these data only indicate a partial rather than a complete shutdown of proviral transcription. Importantly, the extent of suppression of viral expression in natural HTLV-1 infection is not yet known. However, even partial suppression should provide significant survival advantage to an HTLV-1-infected cell since these cells might be less prone to elimination by the immune system, which would be particularly dependent on CTL activity. Furthermore, impairment of CTL surveillance may similarly allow HTLV-1-transformed leukemic cells to survive and proliferate $[47,48]$.

\section{Multifaceted Processes in the Transformation of Infected Cells}

Over time, a subset (2\%-6\%) of HTLV-1-infected individuals will develop ATL [49]. One of the current models is that the Tax oncoprotein confers survival and proliferative properties to infected 
cells (Figure 1) [50-52]. Tax is post-translationally modified by phosphorylation, ubiquitination, and acetylation [53-59]. These post-translational modifications have been shown to be important for Tax function [54,58]. Expression of Tax alone has been postulated to be sufficient for immortalization, but not transformation, of human T-cells $[60,61]$. The in vivo transforming capacity of Tax has been extensively investigated using transgenic mouse models; results suggest that Tax expression can solely drive in vivo tumor formation [62-64]. However, frequent appearance of type 2 defective proviruses (i.e., lacking the $5^{\prime}$ LTR and the Tax gene) in ATL cells lead into questioning these current models [65-67]. Investigation of the mechanisms underlying the generation of these defective proviruses by Miyazaki et al. [67] showed that $41 \%$ of type 2 defective proviruses lacking $5^{\prime}$ LTR were formed before proviral integration. Since Tax expression alone is not enough to transform primary human cells in vitro $[60,61,68]$, it is likely that, similar to human papillomavirus E6 and E7, which cooperate for the development of tumors [69], tax functions cooperatively with other HTLV-1-encoded genes in HTLV-1 to induce human leukemogenesis [63]. Further studies are required to better clarify the roles of the Tax in ATL onset.

\section{HTLV-1 Antisense HBZ Transcripts and Viral Pathogenesis}

While HTLV-1 plus strand (sense) contains transcripts driven from the $5^{\prime}$ LTR, the $3^{\prime}$ LTR produces an antisense transcript, which encodes a protein called HTLV-1 basic Zip factor , HBZ (Figure 1) [7]. The promoter for the $h b z$ gene is contained in the U5 sequence of the $3^{\prime}$ LTR [7]. Analyses showed that HTLV-1 LTR possess a bidirectional transcriptional activity. Interestingly, Sp1 sites within this region are critical for the control of bidirectional and HBZ transcription [70,71]. While tax transcripts are detected in few transformed ATL cells, $h b z$ mRNA is present in all ATL cells [72-74].

Through its basic Zip (bZIP) domain, the HBZ protein has been described to interact with transcription factors the cAMP-response element binding proteins (CREB, CREB-2), the cAMP-responsive element modulator (CREM-Ia) the activating transcription factor ATF-1 [75], c-Jun [76,77], JunB [78], and JunD [79], and was originally reported to suppress Tax-mediated viral transcription [8]. Furthermore, HBZ selectively inhibits the classical nuclear factor-kappa B (NF- $\mathrm{kB}$ ) pathway by inhibiting DNA binding of p65 and promoting its degradation [80]. On the other hand, Tax has been shown to rather activate both classical and alternative NF- $\mathrm{KB}$ pathways [81]. Since the two pathways differentially control the expression of genes with anti-apoptotic functions in lymphoma cell lines [82], preferential activation of the alternative pathway by Tax and HBZ might be implicated in the proliferation of ATL cells. Interestingly, a previous study had suggested that the $h b z$ mRNA itself is also important for the induction of proliferation of HTLV-1-infected cells [9]. Moreover, it has been shown that HTLV-1 molecular clones harboring a mutation in the leucine zipper domain of HBZ exhibit reduced proviral load compared to wild type virus when inoculated into rabbits [83]. Furthermore, HBZ has been reported to increase the activity of human telomerase reverse transcriptase (hTERT) [84]. Collectively, all of the available data support that HBZ protein and RNA play important roles in promoting viral replication and cellular proliferation [85].

Genetic instability in infected cells might allow them to escape strong CTL response, and further protect them from clonal dominance [86]. On the other hand, HTLV-1-triggered alterations in cellular gene expression have been proposed to amount to a mutator phenotype that promotes leukemogenesis [87]. Thus far, Tax has been recognized as the main source of HTLV-1-associated genetic instability. In a recent study, Vernin et al. [88] showed that HBZ promotes onco-miR expression as well as DNA-strand breaks by downregulating the expression of OBFC2A protein via posttranscriptional activation of miR17 and miR21. OBFC2A intervenes with ATM signaling and subsequently activates DNA repair and cell-cycle checkpoints [88]. In their study, Vernin et al. further suggested that preleukemic phenotypes of HTLV-1-positive CD4+ T cells is portrayed by an oncogenic miRNA profile that is promoted by HBZ [88].

The transforming capacity of HBZ has been clearly demonstrated in vitro and in vivo using HBZ transgenic (Tg) mice [89,90]. Using the 5' LTR deleted K30 4089 molecular clone [10], Gazon et al. have 
demonstrated that, in murine cells, HBZ expression on its own drives cellular proliferation and colony formation in soft agar [90]. Furthermore, in vivo studies showed that CD4+ Foxp3-positive T-cells from HBZ-Tg mice had similar effector/memory [89] and regulatory phenotypes to infected CD4+ T cells from ATL patients or HTLV-1-infected carriers [91,92] In this study by Satou et al., transgenic mice expressing Tax under the same promoter as the HBZ-Tg mice did not display any changes in their Treg phenotype [89]. These data suggest that HBZ, rather than Tax, is responsible for conferring a specific phenotype to HTLV-1-infected cells and ATL cells.

The interplay between Tax and HBZ in T-cell transformation might then be explained by the fact that the former would be needed to initiate transformation while the latter would be required to maintain the transformed phenotype of ATL cells at a time point when Tax expression is extinguished. However, when taking into consideration the accumulating evidence on HBZ functions, the notion that Tax only can initiate cellular transformation via its ability to induce genetic instability may require some revision. Indeed, it has been clearly established that $\mathrm{HBZ}$ is responsible for the specific phenotype, function and proliferation of HTLV-1-infected CD4+ T-cells and ATL cells, and that, in addition to Tax, HBZ plays an important role in the oncogenic activity of HTLV-1 (Figure 2). Furthermore, the long latent period observed by Satou et al. before the onset of T-cell lymphomas in HBZ-Tg mice suggests that additional epigenetic alterations in CD4+ T-cells are necessary for the development of T-cell lymphomas in HBZ-Tg mice as well as for ATL [89]. In conclusion, functions recently attributed to HBZ provide novel insights into the interaction between HTLV and its host and may be exploited to treat and prevent HTLV-1-induced diseases.

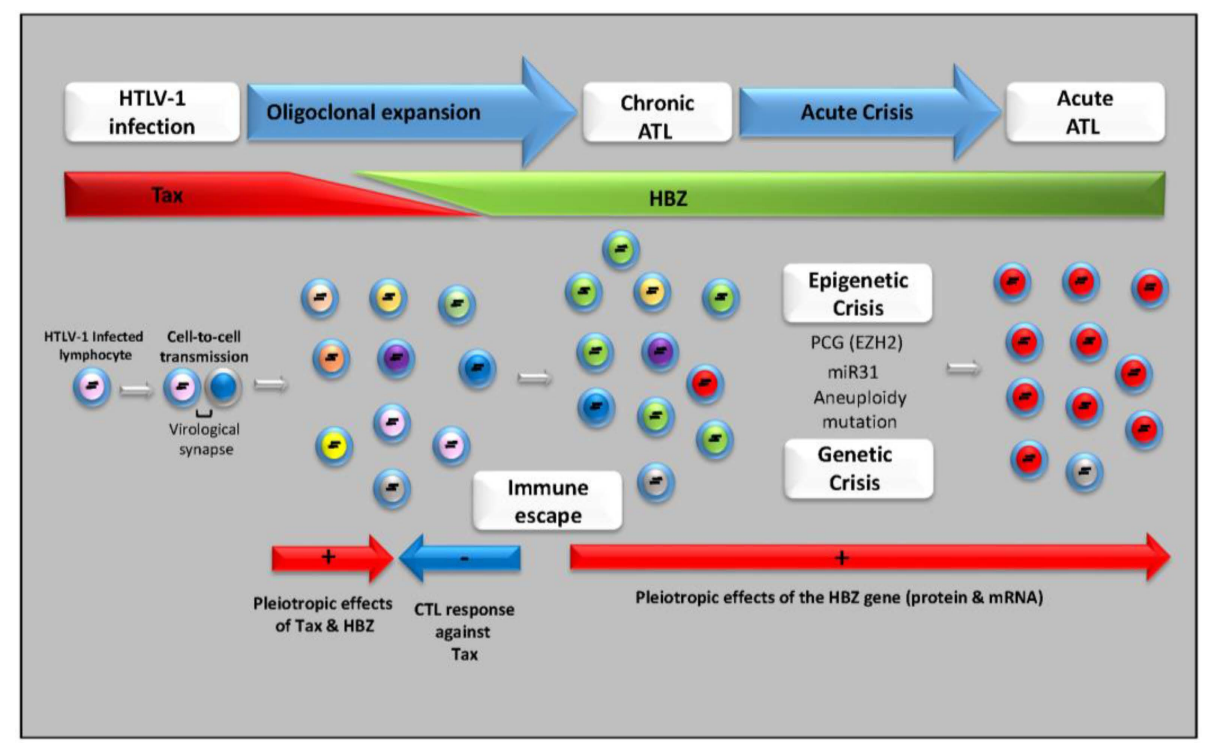

Figure 2. Model for ATL development. HTLV-1 is transmitted in a cell-to-cell fashion via a virological synapse. After infection, HTLV-1 promotes clonal proliferation of infected cells by pleiotropic actions of Tax and other viral proteins. Tax is considered crucial for the oligoclonal maintenance and expansion of HTLV-1-infected cells during the early phase but is only transiently expressed by HTLV-1-infected cells. Proliferation of HTLV-1-infected cells is controlled by cytotoxic T-cells in vivo. Thereafter, continuing expression of HBZ is followed by genetic/epigenetic loss of function of tumor suppressor genes and modulation of micro RNA levels. After a long latent period, ATL develops in about $5 \%$ of asymptomatic carriers. Diverse genetic abnormalities are acquired during the progression to ATL from an indolent to an aggressive disease form.

\section{Therapeutic Approaches for ATL}

ATL is an incurable and poorly treatable disease. Despite advances in both chemotherapy and supportive care, median survival time of patients remains less than one year [93]. As pointed out by 
Yamada and Tomonaga [94], an important amount of knowledge in molecular biology and oncogenesis of ATL has accumulated but has not yet been translated into improved prognosis of affected patients [94]. In fact, it has been reported that the prognosis of indolent subtypes, chronic and smoldering ATL, was 4.1 years, which is poorer than previously thought [95]. Therapeutic approaches using interferon- $\alpha$ combined with zidovudine have nonetheless been reported to be highly effective treatments for indolent ATL and, as they have been extensively reviewed, will not be further detailed here [96-98].

\subsection{Chemotherapy}

In Europe, US and Brazil, the recommended treatment of patients with acute or lymphoma-type ATL is based on the use of combined chemotherapy, as a first line therapy: cyclophosphamide, adriamycin, vincristine, and prednisolone (CHOP). $46.5 \%$ of patients treated with CHOP exhibit partial remission (PR), while only $\sim 20 \%$ are achieving complete remission (CR) [99]. Intensification of CHOP with etoposide, vindesine, ranimustine, and mitoxantrone resulted in CR for $35.8 \%$ of ATL patients [100]. However, the median survival was only 8-8.5 months in these studies with predicted survivals of $13 \%$ after three years. In Japan, the first line of combined chemotherapy against ATL consists of VCAP-AMP-VECP) (i.e; vincristine, cyclophosphamide, doxorubicin, and prednisone (VCAP), doxorubicin, ranimustine, and prednisone (AMP), and vindesine, etoposide, carboplatin, and prednisone (VECP)) [101-103]. It has in fact been shown that the CR rate was better with VCAP-AMP-VECP $(40 \%)$ than biweekly CHOP $(\sim 20 \%)$ and that a three-year survival rate of patients treated with VCAP-AMP-VECP therapy improved by $24 \%$ (versus $13 \%$ with CHOP treatment) [104]. The two main obstacles to combined chemotherapy are (1) the inherent drug resistance to chemotherapeutic agents observed in ATL cells [49] and (2) the profoundly weakened and immunodeficient state of ATL patients. Overall, ATL survival with various chemotherapy regimens is poor, with survival ranging between 5.5 and 13 months in several cohorts of patients, and more predominantly in patients with acute leukemia or lymphoma. At the moment, this approach does not represent a prospect for a cure.

\subsection{Molecular Targeted Therapy}

As an alternative to chemotherapy, a number of studies have addressed the potential use of nucleoside analogues for the treatment of ATL. The purine analog $2^{\prime}$-deoxycoformycin (DCF) that inhibits adenosine deaminase has been studied. In a phase II study using DCF, two CR (8\%) and one PR (4\%) cases were reported among 25 patients with ATL [105]. Unfortunately, these response rates are significantly lower than those with CHOP-based chemotherapy. Using DCF in conjunction with CHOP, $52 \%$ of ATL patients achieved CR, but the median survival of patients was only 7.4 months [106]. Interestingly, another study reported that a patient presenting resistant acute ATL had an improved and lasting partial response when treated with another adenosine analog, $2^{\prime}$-chlorodeoxyadenosine (cladribine) [107]. However the follow-up phase II study showed very limited benefit with this compound. It is nonetheless important to note that all patients under treatment showed resistant ATL prior to treatment in this study and therefore represented a poor prognosis group [108].

Parallel approaches, using analogs or inhibitors of topoisomerase, such as irinotecan hydrochloride (CPT-11) [109], a bis (2,6-dioxopiperazine) analog (MST-16) [110], Menogaril [111] or all-trans-retinoic acid (ATRA) [112,113], an analog of vitamin A have been similarly tested. The most promising results were obtained with the MST-16 treatment. In a cohort constituted of 21 acute-type ATL patients, treatment resulted in one CR and five PR. Among eight lymphoma-type ATL patients, two PR cases were identified, while out of two chronic-type ATL patients, one was diagnosed as being in CR while the other, as being in PR. Remissions were achieved within 23 days and lasted over two months (median, 68 days) [110]. These results do not clearly represent an improvement over conventional chemotherapy and further studies with MST-16 are needed.

Gene expression governed by epigenetic changes is crucial for the pathogenesis of cancer. Histone deacetylases are enzymes that are involved in the remodeling of chromatin and play a key role in 
the epigenetic regulation of gene expression. The use of histone deacetylase inhibitors (HDACi) to treat ATL has recently attracted attention. The HDACi LBH589 (panobinostat) exhibited significant anti-ATL activity by activating a novel RAIDD-caspase- 2 pathway in mice and by modulating the expression of Tax and CCR4 [114]. However, a phase II study using panobinostat for cutaneous T-Cell Lymphoma (CTCL) and indolent ATL patients had to be terminated because of severe side effects and appearance of ulcers in patients with ATL [115].

Depsipeptide (HFR901228), another HDACi induces apoptosis in all tested HTLV-1-infected cell lines and in primary cells from patients with acute ATL, through a reduction of NF-kB and AP-1 transactivation activity, and downregulation of B-cell lymphoma-extra large (Bcl-xL) and cyclin D2 expression. Partial inhibition of tumor growth following transplantation of HTLV-1-infected cells, was seen in a severe combined immunodeficiency (SCID) mouse model [116]. Further studies are needed to evaluate the efficacy of HFR901228.

Sodium valproate (VPA) is another HDCAi under investigation, which is widely prescribed for the treatment of epilepsy, bipolar mood disorders, and migraine, and which shows HDACi activity among several other potential antitumor properties [117]. VPA is also being investigated for its inclusion in maintenance therapy after chemotherapy [118]. More importantly, dramatic clearance of both lymphoma and leukemic cells has been demonstrated in Bovine Leukemia Virus-induced B-cell malignancy in sheep upon treatment [37,119]. In a recent study, Belrose et al. [38] analyzed the impact of VPA treatment on the expression profile of Tax and HBZ in freshly cultured cells from HTLV-1-infected patients. It was then proposed that VPA relieved the epigenetic control over Tax expression, thereby exposing latently HTLV-1-infected cells to the immune response. Indeed, in the presence of VPA, Tax expression kinetics were profoundly modified, with Tax mRNA levels increasing constantly over time, suggesting dysregulation of the processes responsible for the control of its expression in lymphocytes from HAM/TSP patients, but not from asymptomatic carriers. One interesting finding from the Belrose et al. study was that VPA strongly impaired the expression of HBZ [38]. The authors suggested that the opposite effect of VPA on Tax and HBZ expression might be caused by the nature of HDAC complexes present on the $5^{\prime}-$ and $3^{\prime}-\mathrm{HTLV}-1$ promoters in relation to their selective down-modulating properties. Alternatively, it cannot be excluded that activation of sense transcription by Tax and VPA might have impaired antisense transcription, either by competition for transcription factors or interference with its initiation. Indeed, Cavanagh et al. [10] have showed that, by deleting the $5^{\prime}$-LTR, sense transcription has a negative impact on antisense transcription (i.e., from the $3^{\prime}$-LTR) [10]. Interestingly, despite increased Tax expression, Belrose et al. did not observe the expected increase in proviral load (PVL) in VPA-treated samples from HAM/TSP. Instead, a significant decrease of the PVL in VPA-treated samples from acute ATL patients was observed, suggesting a decrease in the percentage of ATL cells [120]. Using VPA to augment the level of histone acetylation and increase HTLV-1 gene expression in cultured cells from HAM/TSP patients, Mosley et al. [121] demonstrated that, while the level of Tax expression doubled after overnight treatment, the rate of CD8+ T-cell-mediated lysis of Tax-expressing cells was reduced by 50\% [121]. VPA thus appeared to inhibit CD8+ T-cell-mediated cell from killing itself. These observations indicate that HDCAis may reduce the efficiency of CTL surveillance of HTLV-1. Further studies are needed to evaluate the use of HDIs in nonmalignant cases of HTLV-1 infection. Taken together, these observations strongly suggest that HBZ is a very interesting therapeutic target and that a therapy using VPA as part of the management of patients with acute and lymphoma ATL should be considered for the prevention of progression of chronic and smoldering ATL. Should a protective effect be shown, the long-standing safety profile of this compound would justify a prospective study in which its efficacy in preventing ATL in patients considered to be at high risk of disease is evaluated [122].

\subsection{Immunotherapy}

Another alternative approach is to target ATL cells using specific markers on the surface of the malignant cells with monoclonal antibodies. One of the first potential tested target is the interleukin 
(IL)-2alpha receptor $\alpha$ chain, CD25. Indeed, ATL cells express high level of CD25 on their surface. In their recent phase I/II trial on 34 patients with ATL, Berkowitz et al. [123] reported that daclizumab, a humanized monoclonal antibody which blocks IL-2 binding by recognizing CD25 on ATL cells, was associated with effective clinical responses in patients with indolent disease, although no beneficial responses were observed in patients with acute or lymphomatous subtypes of ATL [123]. The finding that daclizumab has antitumor activity and demonstrates a potential in achieving long-term responses in patients with the indolent form of ATL, suggest that immunotherapy offers a therapeutic option to prevent indolent diseases to develop into aggressive ATL [123].

Another target for immuno-based therapy against ATL is the CC chemokine receptor 4 (CCR4). CCR4 is principally expressed on regulatory T-cells (Tregs) and helper T-cells (Th), where it functions in inducing homing of these leukocytes to sites of inflammation. Tregs play an essential role in maintaining immune balance; however, in malignancy, Tregs impair host antitumor immunity and provide a favorable environment for tumors to grow [49]. Furthermore, ATL cells express high levels of CCR4 on their surface [124]. Mogamulizumab (KW-0761) is the first approved glyco-engineered therapeutic monoclonal antibody to target CCR4. $30 \%$ of patients with acute forms of ATL (5 out of 15) treated with Mogamulizumab showed a positive response [125]. Several ongoing clinical trials in Japan are investigating if combining Mogamulizumab with a chemotherapy treatment could be beneficial [126-128].

\subsection{Stem Cell Transplantation}

As a treatment strategy for ATL, allogeneic hematopoietic stem cell transplantation (allo-HSCT) with reduced intensity conditioning regimens (RIC) was prospectively evaluated. Several teams have reported the safety and feasibility of allo-HSCT with RIC using peripheral blood stem cells from an HLA-matched sibling donor in patients with acute ATL, who achieved remission after chemotherapy [129-131]. These studies showed that the overall survival (OS) at three years after allo-HSCT with RIC treatment ranged from $33 \%$ to $49 \%$ [132]. Interestingly, a significant decrease of the proviral load was also reported in many of these patients. These findings suggest that cell-mediated immunity to HTLV-1 was augmented in these patients, which might account for the efficacy of this therapy. In fact, Graft-versus-host disease (GVHD) is a good prognostic factor for ATL patients [130], indicating that an immune attack by donor lymphocytes is critical for the efficacy of treatment. Kanda et al. [133] reported that grade I/II acute GVHD was associated with a longer OS. Beneficial effects of allo-HSCT on non-Japanese ATL patients were recently confirmed by a retrospective study from the European Group for Blood and Marrow Transplantation's Lymphoma Working Party [134].

\section{Perspectives and Conclusions}

Although new therapeutic options are emerging, treatment of ATL patients remains challenging. The initial pathogenic event for ATL is HTLV-1 genomic integration; however, additional genetic alterations have also been implicated in ATL pathogenesis. Umino et al. [135] reported on the importance of clonal heterogeneity of ATL cells involving different genomic alterations; they further demonstrated that these cells originated from a common cell. It was suggested that approximately $70 \%$ of ATL cases undergo clonal evolution, and that genetic instability may contribute to the accumulation of genomic alterations [135]. In fact, the existence of multiple clones with genomic instability is one factor that renders ATL cells resistant to conventional chemotherapy. Even if a proportion of cells are killed by chemotherapy, new resistant clones likely emerge. Therefore, allo-HSCT might be efficient in curing ATL patients by eliminating HTLV-1-integrated recipient ATL clones through strong immune response, and subsequent replacement of the hematopoietic system with donor cells.

Whole genome sequencing revealed that carriers have $10^{3}$ to $10^{4}$ distinct clones with different HTLV-1 integration sites, and that most clones harbored one copy of HTLV-1 proviral DNA [136]. This indicates that HTLV-1 carriers potentially have $10^{3}$ to $10^{4}$ malignant clones. If the number of infected cells increases, there is a greater possibility that malignant transformation might occur. In order to 
reduce the number of pre-malignant cells in HTLV-1 carriers and thus prevent the development of ATL, treatment with HDAC inhibitors seems to be a promising strategy. Indeed vorinostat (suberoylanilide hygroxamic acid: SAHA), panobinostat (LBH-589) and MS-275 have been demonstrated to impede the growth of HTLV-1-infected cell lines and freshly isolated infected cells [137]. Furthermore, as reported by Belrose et al. [38], the link between VPA-induced apoptosis of HTLV-1-infected cell lines, decrease of proviral load in freshly isolated infected cells and loss of HBZ expression indicates that HBZ is a promising therapeutic target. However, further studies are needed to clarify the effect of HDACi on HBZ, although the inclusion of HDACi in clinical trials for the treatment of ATL is expected. Nevertheless, to increase the likehood of discovery of a cure for ATL, rigorous investigation remains necessary for optimizing therapeutic combinations, preventing ATL development in HTLV-1 carriers, and reducing the number of HTLV-1 carriers.

Author Contributions: Jean-Michel Mesnard and Jean-Marie Peloponese wrote the manuscript; Benoit Barbeau and Raymond Césaire critically revised the manuscript.

Conflicts of Interest: The authors declare no conflict of interest.

\section{References}

1. Poiesz, B.J.; Ruscetti, F.W.; Gazdar, A.F.; Bunn, P.A.; Minna, J.D.; Gallo, R.C. Detection and isolation of type $\mathrm{C}$ retrovirus particles from fresh and cultured lymphocytes of a patient with cutaneous T-cell lymphoma. Proc. Natl. Acad. Sci. USA 1980, 77, 7415-7419. [CrossRef] [PubMed]

2. Popovic, M.; Reitz, M.S., Jr.; Sarngadharan, M.G.; Robert-Guroff, M.; Kalyanaraman, V.S.; Nakao, Y.; Miyoshi, I.; Minowada, J.; Yoshida, M.; Ito, Y.; et al. The virus of Japanese adult T-cell leukaemia is a member of the human T-cell leukaemia virus group. Nature 1982, 300, 63-66. [CrossRef] [PubMed]

3. Yoshida, M.; Miyoshi, I.; Hinuma, Y. Isolation and characterization of retrovirus from cell lines of human adult T-cell leukemia and its implication in the disease. Proc. Natl. Acad. Sci. USA 1982, 79, 2031-2035. [CrossRef] [PubMed]

4. Gessain, A.; Cassar, O. Epidemiological Aspects and World Distribution of HTLV-1 Infection. Front. Microbiol. 2012, 3, 388. [CrossRef] [PubMed]

5. Gessain, A.; Barin, F.; Vernant, J.C.; Gout, O.; Maurs, L.; Calender, A.; de Thé, G. Antibodies to human T-lymphotropic virus type-I in patients with tropical spastic paraparesis. Lancet 1985, 2, 407-410. [CrossRef]

6. Osame, M.; Igata, A. The history of discovery and clinico-epidemiology of HTLV-I-associated myelopathy(HAM). Jpn. J. Med. 1989, 28, 412-414. [CrossRef] [PubMed]

7. Barbeau, B.; Mesnard, J.M. Making Sense out of Antisense Transcription in Human T-Cell Lymphotropic Viruses (HTLVs). Viruses 2011, 3, 456-468. [CrossRef] [PubMed]

8. Gaudray, G.; Gachon, F.; Basbous, J.; Biard-Piechaczyk, M.; Devaux, C.; Mesnard, J.M. The complementary strand of the human T-cell leukemia virus type 1 RNA genome encodes a bZIP transcription factor that down-regulates viral transcription. J. Virol. 2002, 76, 12813-12822. [CrossRef] [PubMed]

9. Satou, Y.; Yasunaga, J.; Yoshida, M.; Matsuoka, M. HTLV-I basic leucine zipper factor gene mRNA supports proliferation of adult T cell leukemia cells. Proc. Natl. Acad. Sci. USA 2006, 103, 720-725. [CrossRef] [PubMed]

10. Cavanagh, M.H.; Landry, S.; Audet, B.; Arpin-Andre, C.; Hivin, P.; Pare, M.E.; Thete, J.; Wattel, E.; Marriott, S.J.; Mesnard, J.M.; et al. HTLV-I antisense transcripts initiating in the $3^{\prime}$ LTR are alternatively spliced and polyadenylated. Retrovirology 2006, 3, 15. [CrossRef] [PubMed]

11. Matsuoka, M.; Green, P.L. The HBZ gene, a key player in HTLV-1 pathogenesis. Retrovirology 2009, 6, 71. [CrossRef] [PubMed]

12. Jones, K.S.; Petrow-Sadowski, C.; Huang, Y.K.; Bertolette, D.C.; Ruscetti, F.W. Cell-free HTLV-1 infects dendritic cells leading to transmission and transformation of CD4(+) T cells. Nat. Med. 2008, 14, 429-436. [CrossRef] [PubMed]

13. Manel, N.; Kim, F.J.; Kinet, S.; Taylor, N.; Sitbon, M.; Battini, J.L. The ubiquitous glucose transporter GLUT-1 is a receptor for HTLV. Cell 2003, 115, 449-459. [CrossRef]

14. Wielgosz, M.M.; Rauch, D.A.; Jones, K.S.; Ruscetti, F.W.; Ratner, L. Cholesterol dependence of HTLV-I infection. AIDS Res. Hum. Retrovir. 2005, 21, 43-50. [CrossRef] [PubMed] 
15. Lambert, S.; Bouttier, M.; Vassy, R.; Seigneuret, M.; Petrow-Sadowski, C.; Janvier, S.; Heveker, N.; Ruscetti, F.W.; Perret, G.; Jones, K.S.; et al. HTLV-1 uses HSPG and neuropilin-1 for entry by molecular mimicry of VEGF165. Blood 2009, 113, 5176-5185. [CrossRef] [PubMed]

16. Yasunaga, J.; Matsuoka, M. Molecular mechanisms of HTLV-1 infection and pathogenesis. Int. J. Hematol. 2011, 94, 435-442. [CrossRef] [PubMed]

17. Jones, K.S.; Fugo, K.; Petrow-Sadowski, C.; Huang, Y.; Bertolette, D.C.; Lisinski, I.; Cushman, S.W.; Jacobson, S.; Ruscetti, F.W. Human T-cell leukemia virus type 1 (HTLV-1) and HTLV-2 use different receptor complexes to enter T cells. J. Virol. 2006, 80, 8291-8302. [CrossRef] [PubMed]

18. Zane, L.; Sibon, D.; Legras, C.; Lachuer, J.; Wierinckx, A.; Mehlen, P.; Delfau-Larue, M.H.; Gessain, A.; Gout, O.; Pinatel, C.; et al. Clonal expansion of HTLV-1 positive CD8+ cells relies on cIAP-2 but not on c-FLIP expression. Virology 2010, 407, 341-351. [CrossRef] [PubMed]

19. Igakura, T.; Stinchcombe, J.C.; Goon, P.K.; Taylor, G.P.; Weber, J.N.; Griffiths, G.M.; Tanaka, Y.; Osame, M.; Bangham, C.R. Spread of HTLV-I between lymphocytes by virus-induced polarization of the cytoskeleton. Science 2003, 299, 1713-1716. [CrossRef] [PubMed]

20. Nejmeddine, M.; Negi, V.S.; Mukherjee, S.; Tanaka, Y.; Orth, K.; Taylor, G.P.; Bangham, C.R. HTLV-1-Tax and ICAM-1 act on T-cell signal pathways to polarize the microtubule-organizing center at the virological synapse. Blood 2009, 114, 1016-1025. [CrossRef] [PubMed]

21. Pais-Correia, A.M.; Sachse, M.; Guadagnini, S.; Robbiati, V.; Lasserre, R.; Gessain, A.; Gout, O.; Alcover, A.; Thoulouze, M.I. Biofilm-like extracellular viral assemblies mediate HTLV-1 cell-to-cell transmission at virological synapses. Nat. Med. 2010, 16, 83-89. [CrossRef] [PubMed]

22. Majorovits, E.; Nejmeddine, M.; Tanaka, Y.; Taylor, G.P.; Fuller, S.D.; Bangham, C.R. Human T-lymphotropic virus-1 visualized at the virological synapse by electron tomography. PLoS ONE 2008, 3, e2251. [CrossRef] [PubMed]

23. Mazurov, D.; Ilinskaya, A.; Heidecker, G.; Lloyd, P.; Derse, D. Quantitative comparison of HTLV-1 and HIV-1 cell-to-cell infection with new replication dependent vectors. PLoS Pathog. 2010, 6, e1000788. [CrossRef] [PubMed]

24. Taylor, G.P.; Goon, P.; Furukawa, Y.; Green, H.; Barfield, A.; Mosley, A.; Nose, H.; Babiker, A.; Rudge, P.; Usuku, K.; et al. Zidovudine plus lamivudine in Human T-Lymphotropic Virus type-I-associated myelopathy: A randomised trial. Retrovirology 2006, 3, 63. [CrossRef] [PubMed]

25. Cavrois, M.; Leclercq, I.; Gout, O.; Gessain, A.; Wain-Hobson, S.; Wattel, E. Persistent oligoclonal expansion of human T-cell leukemia virus type 1-infected circulating cells in patients with Tropical spastic paraparesis/HTLV-1 associated myelopathy. Oncogene 1998, 17, 77-82. [CrossRef] [PubMed]

26. Etoh, K.; Tamiya, S.; Yamaguchi, K.; Okayama, A.; Tsubouchi, H.; Ideta, T.; Mueller, N.; Takatsuki, K.; Matsuoka, M. Persistent clonal proliferation of human T-lymphotropic virus type I-infected cells in vivo. Cancer Res. 1997, 57, 4862-4867. [PubMed]

27. Virgin, H.W.; Wherry, E.J.; Ahmed, R. Redefining chronic viral infection. Cell 2009, 138, 30-50. [CrossRef] [PubMed]

28. Johnson, J.M.; Nicot, C.; Fullen, J.; Ciminale, V.; Casareto, L.; Mulloy, J.C.; Jacobson, S.; Franchini, G. Free major histocompatibility complex class I heavy chain is preferentially targeted for degradation by human T-cell leukemia/lymphotropic virus type 1 p12(I) protein. J. Virol. 2001, 75, 6086-6094. [CrossRef] [PubMed]

29. Jacobson, S.; Shida, H.; McFarlin, D.E.; Fauci, A.S.; Koenig, S. Circulating CD8+ cytotoxic T lymphocytes specific for HTLV-I pX in patients with HTLV-I associated neurological disease. Nature 1990, 348, $245-248$. [CrossRef] [PubMed]

30. Kannagi, M.; Harada, S.; Maruyama, I.; Inoko, H.; Igarashi, H.; Kuwashima, G.; Sato, S.; Morita, M.; Kidokoro, M.; Sugimoto, M.; et al. Predominant recognition of human T cell leukemia virus type I (HTLV-I) pX gene products by human CD8+ cytotoxic T cells directed against HTLV-I-infected cells. Int. Immunol. 1991, 3, 761-767. [CrossRef] [PubMed]

31. Goon, P.K.; Biancardi, A.; Fast, N.; Igakura, T.; Hanon, E.; Mosley, A.J.; Asquith, B.; Gould, K.G.; Marshall, S.; Taylor, G.P.; et al. Human T cell lymphotropic virus (HTLV) type-1-specific CD8+ T cells: Frequency and immunodominance hierarchy. J. Infect. Dis. 2004, 189, 2294-2298. [CrossRef] [PubMed]

32. Nagasato, K.; Nakamura, T.; Shirabe, S.; Shibayama, K.; Ohishi, K.; Ichinose, K.; Tsujihata, M.; Nagataki, S. Presence of serum anti-human T-lymphotropic virus type I (HTLV-I) IgM antibodies means persistent active replication of HTLV-I in HTLV-I-associated myelopathy. J. Neurol. Sci. 1991, 103, 203-208. [CrossRef] 
33. Kira, J.; Nakamura, M.; Sawada, T.; Koyanagi, Y.; Ohori, N.; Itoyama, Y.; Yamamoto, N.; Sakaki, Y.; Goto, I. Antibody titers to HTLV-I-p40tax protein and gag-env hybrid protein in HTLV-I-associated myelopathy/tropical spastic paraparesis: Correlation with increased HTLV-I proviral DNA load. J. Neurol. Sci. 1992, 107, 98-104. [CrossRef]

34. Ishihara, S.; Okayama, A.; Stuver, S.; Horinouchi, H.; Shioiri, S.; Murai, K.; Kubota, T.; Yamashita, R.; Tachibana, N.; Tsubouchi, H.; et al. Association of HTLV-I antibody profile of asymptomatic carriers with proviral DNA levels of peripheral blood mononuclear cells. J. Acquir. Immune Defic. Syndr. 1994, 7, 199-203. [PubMed]

35. Hanon, E.; Hall, S.; Taylor, G.P.; Saito, M.; Davis, R.; Tanaka, Y.; Usuku, K.; Osame, M.; Weber, J.N.; Bangham, C.R. Abundant tax protein expression in CD4+ T cells infected with human T-cell lymphotropic virus type I (HTLV-I) is prevented by cytotoxic T lymphocytes. Blood 2000, 95, 1386-1392. [PubMed]

36. Lezin, A.; Gillet, N.; Olindo, S.; Signate, A.; Grandvaux, N.; Verlaeten, O.; Belrose, G.; de Carvalho Bittencourt, M.; Hiscott, J.; Asquith, B.; et al. Histone deacetylase mediated transcriptional activation reduces proviral loads in HTLV-1 associated myelopathy/tropical spastic paraparesis patients. Blood 2007, 110, 3722-3728. [CrossRef] [PubMed]

37. Lezin, A.; Olindo, S.; Belrose, G.; Signate, A.; Cesaire, R.; Smadja, D.; Macallan, D.; Asquith, B.; Bangham, C.; Bouzar, A.; et al. Gene activation therapy: From the BLV model to HAM/TSP patients. Front. Biosci. (Schol. Ed.) 2009, 1, 205-215. [CrossRef] [PubMed]

38. Belrose, G.; Gross, A.; Olindo, S.; Lezin, A.; Dueymes, M.; Komla-Soukha, I.; Smadja, D.; Tanaka, Y.; Willems, L.; Mesnard, J.M.; et al. Effects of valproate on Tax and HBZ expression in HTLV-1 and HAM/TSP T lymphocytes. Blood 2011, 118, 2483-2491. [CrossRef] [PubMed]

39. Afonso, P.V.; Mekaouche, M.; Mortreux, F.; Toulza, F.; Moriceau, A.; Wattel, E.; Gessain, A.; Bangham, C.R.; Dubreuil, G.; Plumelle, Y.; et al. Highly active antiretroviral treatment against STLV-1 infection combining reverse transcriptase and HDAC inhibitors. Blood 2010, 116, 3802-3808. [CrossRef] [PubMed]

40. Asquith, B.; Mosley, A.J.; Heaps, A.; Tanaka, Y.; Taylor, G.P.; McLean, A.R.; Bangham, C.R. Quantification of the virus-host interaction in human T lymphotropic virus I infection. Retrovirology 2005, 2, 75. [CrossRef] [PubMed]

41. Hilburn, S.; Rowan, A.; Demontis, M.A.; MacNamara, A.; Asquith, B.; Bangham, C.R.; Taylor, G.P. In vivo expression of human T-lymphotropic virus type 1 basic leucine-zipper protein generates specific CD8+ and CD4+ T-lymphocyte responses that correlate with clinical outcome. J. Infect. Dis. 2011, 203, 529-536. [CrossRef] [PubMed]

42. Macnamara, A.; Rowan, A.; Hilburn, S.; Kadolsky, U.; Fujiwara, H.; Suemori, K.; Yasukawa, M.; Taylor, G.; Bangham, C.R.; Asquith, B. HLA class I binding of HBZ determines outcome in HTLV-1 infection. PLoS Pathog. 2010, 6, e1001117. [CrossRef] [PubMed]

43. Hidaka, M.; Inoue, J.; Yoshida, M.; Seiki, M. Post-transcriptional regulator (rex) of HTLV-1 initiates expression of viral structural proteins but suppresses expression of regulatory proteins. EMBO J. 1988, 7, 519-523. [PubMed]

44. Nicot, C.; Dundr, M.; Johnson, J.M.; Fullen, J.R.; Alonzo, N.; Fukumoto, R.; Princler, G.L.; Derse, D.; Misteli, T.; Franchini, G. HTLV-1-encoded p30II is a post-transcriptional negative regulator of viral replication. Nat. Med. 2004, 10, 197-201. [CrossRef] [PubMed]

45. Lemasson, I.; Polakowski, N.J.; Laybourn, P.J.; Nyborg, J.K. Transcription regulatory complexes bind the human T-cell leukemia virus $5^{\prime}$ and $3^{\prime}$ long terminal repeats to control gene expression. Mol. Cell. Biol. 2004, 24, 6117-6126. [CrossRef] [PubMed]

46. Smith, M.J.; Gitlin, S.D.; Browning, C.M.; Lane, B.R.; Clark, N.M.; Shah, N.; Rainier, S.; Markovitz, D.M. GLI-2 modulates retroviral gene expression. J. Virol. 2001, 75, 2301-2313. [CrossRef] [PubMed]

47. Furukawa, Y.; Kubota, R.; Tara, M.; Izumo, S.; Osame, M. Existence of escape mutant in HTLV-I tax during the development of adult T-cell leukemia. Blood 2001, 97, 987-993. [CrossRef] [PubMed]

48. Nomura, M.; Ohashi, T.; Nishikawa, K.; Nishitsuji, H.; Kurihara, K.; Hasegawa, A.; Furuta, R.A.; Fujisawa, J.; Tanaka, Y.; Hanabuchi, S.; et al. Repression of tax expression is associated both with resistance of human T-cell leukemia virus type 1-infected T cells to killing by tax-specific cytotoxic T lymphocytes and with impaired tumorigenicity in a rat model. J. Virol. 2004, 78, 3827-3836. [CrossRef] [PubMed]

49. Matsuoka, M.; Jeang, K.T. Human T-cell leukaemia virus type 1 (HTLV-1) infectivity and cellular transformation. Nat. Rev. Cancer 2007, 7, 270-280. [CrossRef] [PubMed] 
50. Grassmann, R.; Aboud, M.; Jeang, K.T. Molecular mechanisms of cellular transformation by HTLV-1 Tax. Oncogene 2005, 24, 5976-5985. [CrossRef] [PubMed]

51. Higuchi, M.; Fujii, M. Distinct functions of HTLV-1 Tax1 from HTLV-2 Tax2 contribute key roles to viral pathogenesis. Retrovirology 2009, 6, 117. [CrossRef] [PubMed]

52. Basbous, J.; Bazarbachi, A.; Granier, C.; Devaux, C.; Mesnard, J.M. The central region of human T-cell leukemia virus type 1 Tax protein contains distinct domains involved in subunit dimerization. J. Virol. 2003, 77, 13028-13035. [CrossRef] [PubMed]

53. Peloponese, J.M., Jr.; Iha, H.; Yedavalli, V.R.; Miyazato, A.; Li, Y.; Haller, K.; Benkirane, M.; Jeang, K.T. Ubiquitination of human T-cell leukemia virus type 1 tax modulates its activity. J. Virol. 2004, 78, 11686-11695. [CrossRef] [PubMed]

54. Peloponese, J.M., Jr.; Yasunaga, J.; Kinjo, T.; Watashi, K.; Jeang, K.T. Peptidylproline cis-trans-isomerase Pin1 interacts with human T-cell leukemia virus type 1 tax and modulates its activation of NF-kappaB. J. Virol. 2009, 83, 3238-3248. [CrossRef] [PubMed]

55. Durkin, S.S.; Ward, M.D.; Fryrear, K.A.; Semmes, O.J. Site-specific phosphorylation differentiates active from inactive forms of the human T-cell leukemia virus type 1 Tax oncoprotein. J. Biol. Chem. 2006, 281, 31705-31712. [CrossRef] [PubMed]

56. Chiari, E.; Lamsoul, I.; Lodewick, J.; Chopin, C.; Bex, F.; Pique, C. Stable ubiquitination of human T-cell leukemia virus type 1 tax is required for proteasome binding. J. Virol. 2004, 78, 11823-11832. [CrossRef] [PubMed]

57. Lodewick, J.; Lamsoul, I.; Polania, A.; Lebrun, S.; Burny, A.; Ratner, L.; Bex, F. Acetylation of the human T-cell leukemia virus type 1 Tax oncoprotein by p300 promotes activation of the NF-kappaB pathway. Virology 2009, 386, 68-78. [CrossRef] [PubMed]

58. Jeong, S.J.; Ryo, A.; Yamamoto, N. The prolyl isomerase Pin1 stabilizes the human T-cell leukemia virus type 1 (HTLV-1) Tax oncoprotein and promotes malignant transformation. Biochem. Biophys. Res. Commun. 2009, 381, 294-299. [CrossRef] [PubMed]

59. Marriott, S.J.; Semmes, O.J. Impact of HTLV-I Tax on cell cycle progression and the cellular DNA damage repair response. Oncogene 2005, 24, 5986-5995. [CrossRef] [PubMed]

60. Rosin, O.; Koch, C.; Schmitt, I.; Semmes, O.J.; Jeang, K.T.; Grassmann, R. A human T-cell leukemia virus Tax variant incapable of activating NF-kappaB retains its immortalizing potential for primary T-lymphocytes. J. Biol. Chem. 1998, 273, 6698-6703. [CrossRef] [PubMed]

61. Robek, M.D.; Ratner, L. Immortalization of CD4(+) and CD8(+) T lymphocytes by human T-cell leukemia virus type 1 Tax mutants expressed in a functional molecular clone. J. Virol. 1999, 73, 4856-4865. [PubMed]

62. Grossman, W.J.; Kimata, J.T.; Wong, F.H.; Zutter, M.; Ley, T.J.; Ratner, L. Development of leukemia in mice transgenic for the tax gene of human T-cell leukemia virus type I. Proc. Natl. Acad. Sci. USA 1995, 92, 1057-1061. [CrossRef] [PubMed]

63. Hasegawa, H.; Sawa, H.; Lewis, M.J.; Orba, Y.; Sheehy, N.; Yamamoto, Y.; Ichinohe, T.; Tsunetsugu-Yokota, Y.; Katano, H.; Takahashi, H.; et al. Thymus-derived leukemia-lymphoma in mice transgenic for the Tax gene of human T-lymphotropic virus type I. Nat. Med. 2006, 12, 466-472. [CrossRef] [PubMed]

64. Ohsugi, T.; Kumasaka, T.; Okada, S.; Urano, T. The Tax protein of HTLV-1 promotes oncogenesis in not only immature T cells but also mature T cells. Nat. Med. 2007, 13, 527-528. [CrossRef] [PubMed]

65. Matsuoka, M.; Tamiya, S.; Takemoto, S.; Yamaguchi, K.; Takatsuki, K. HTLV-I provirus in the clinical subtypes of ATL. Leukemia 1997, 11 (Suppl. 3), 67-69. [PubMed]

66. Tamiya, S.; Matsuoka, M.; Etoh, K.; Watanabe, T.; Kamihira, S.; Yamaguchi, K.; Takatsuki, K. Two types of defective human T-lymphotropic virus type I provirus in adult T-cell leukemia. Blood 1996, 88, 3065-3073. [PubMed]

67. Miyazaki, M.; Yasunaga, J.; Taniguchi, Y.; Tamiya, S.; Nakahata, T.; Matsuoka, M. Preferential selection of human T-cell leukemia virus type 1 provirus lacking the 5 ' long terminal repeat during oncogenesis. J. Virol. 2007, 81, 5714-5723. [CrossRef] [PubMed]

68. Haller, K.; Kibler, K.V.; Kasai, T.; Chi, Y.H.; Peloponese, J.M.; Yedavalli, V.S.; Jeang, K.T. The N-terminus of rodent and human MAD1 confers species-specific stringency to spindle assembly checkpoint. Oncogene 2006, 25, 2137-2147. [CrossRef] [PubMed]

69. Duensing, S.; Munger, K. Mechanisms of genomic instability in human cancer: Insights from studies with human papillomavirus oncoproteins. Int. J. Cancer 2004, 109, 157-162. [CrossRef] [PubMed] 
70. Yoshida, M.; Satou, Y.; Yasunaga, J.; Fujisawa, J.; Matsuoka, M. Transcriptional control of spliced and unspliced human T-cell leukemia virus type 1 bZIP factor (HBZ) gene. J. Virol. 2008, 82, 9359-9368. [CrossRef] [PubMed]

71. Arpin-Andre, C.; Laverdure, S.; Barbeau, B.; Gross, A.; Mesnard, J.M. Construction of a reporter vector for analysis of bidirectional transcriptional activity of retrovirus LTR. Plasmid 2014, 74, 45-51. [CrossRef] [PubMed]

72. Duc Dodon, M.; Mesnard, J.M.; Barbeau, B. [Adult T-cell leukemia induced by HTLV-1: Before and after HBZ]. Med. Sci. (Paris) 2010, 26, 391-396. [CrossRef] [PubMed]

73. Kataoka, K.; Nagata, Y.; Kitanaka, A.; Shiraishi, Y.; Shimamura, T.; Yasunaga, J.; Totoki, Y.; Chiba, K.; Sato-Otsubo, A.; Nagae, G.; et al. Integrated molecular analysis of adult T cell leukemia/lymphoma. Nat. Genet. 2015, 47, 1304-1315. [CrossRef] [PubMed]

74. Vicente, C.; Cools, J. The genomic landscape of adult T cell leukemia/lymphoma. Nat. Genet. 2015, 47, 1226-1227. [CrossRef] [PubMed]

75. Lemasson, I.; Lewis, M.R.; Polakowski, N.; Hivin, P.; Cavanagh, M.H.; Thebault, S.; Barbeau, B.; Nyborg, J.K.; Mesnard, J.M. Human T-cell leukemia virus type 1 (HTLV-1) bZIP protein interacts with the cellular transcription factor CREB to inhibit HTLV-1 transcription. J. Virol. 2007, 81, 1543-1553. [CrossRef] [PubMed]

76. Basbous, J.; Arpin, C.; Gaudray, G.; Piechaczyk, M.; Devaux, C.; Mesnard, J.M. The HBZ factor of human T-cell leukemia virus type I dimerizes with transcription factors JunB and c-Jun and modulates their transcriptional activity. J. Biol. Chem. 2003, 278, 43620-43627. [CrossRef] [PubMed]

77. Matsumoto, J.; Ohshima, T.; Isono, O.; Shimotohno, K. HTLV-1 HBZ suppresses AP-1 activity by impairing both the DNA-binding ability and the stability of c-Jun protein. Oncogene 2005, 24, 1001-1010. [CrossRef] [PubMed]

78. Hivin, P.; Basbous, J.; Raymond, F.; Henaff, D.; Arpin-Andre, C.; Robert-Hebmann, V.; Barbeau, B.; Mesnard, J.M. The HBZ-SP1 isoform of human T-cell leukemia virus type I represses JunB activity by sequestration into nuclear bodies. Retrovirology 2007, 4, 14. [CrossRef] [PubMed]

79. Thebault, S.; Basbous, J.; Hivin, P.; Devaux, C.; Mesnard, J.M. HBZ interacts with JunD and stimulates its transcriptional activity. FEBS Lett. 2004, 562, 165-170. [CrossRef]

80. Zhao, T.; Yasunaga, J.; Satou, Y.; Nakao, M.; Takahashi, M.; Fujii, M.; Matsuoka, M. Human T-cell leukemia virus type 1 bZIP factor selectively suppresses the classical pathway of NF-kappaB. Blood 2009, 113, 2755-2764. [CrossRef] [PubMed]

81. Peloponese, J.M.; Yeung, M.L.; Jeang, K.T. Modulation of nuclear factor-kappaB by human T cell leukemia virus type 1 Tax protein: Implications for oncogenesis and inflammation. Immunol. Res. 2006, 34, 1-12. [CrossRef]

82. Bernal-Mizrachi, L.; Lovly, C.M.; Ratner, L. The role of NF-\{kappa\}B-1 and NF-\{kappa\}B-2-mediated resistance to apoptosis in lymphomas. Proc. Natl. Acad. Sci. USA 2006, 103, 9220-9225. [CrossRef] [PubMed]

83. Arnold, J.; Zimmerman, B.; Li, M.; Lairmore, M.D.; Green, P.L. Human T-cell leukemia virus type-1 antisense-encoded gene, Hbz, promotes T-lymphocyte proliferation. Blood 2008, 112, 3788-3797. [CrossRef] [PubMed]

84. Kuhlmann, A.S.; Villaudy, J.; Gazzolo, L.; Castellazzi, M.; Mesnard, J.M.; Duc Dodon, M. HTLV-1 HBZ cooperates with JunD to enhance transcription of the human telomerase reverse transcriptase gene (hTERT). Retrovirology 2007, 4, 92. [CrossRef] [PubMed]

85. Barbeau, B.; Mesnard, J.M. Does chronic infection in retroviruses have a sense? Trends Microbiol. 2015, 23, 367-375. [CrossRef] [PubMed]

86. Mortreux, F.; Leclercq, I.; Gabet, A.S.; Leroy, A.; Westhof, E.; Gessain, A.; Wain-Hobson, S.; Wattel, E. Somatic mutation in human T-cell leukemia virus type 1 provirus and flanking cellular sequences during clonal expansion in vivo. J. Natl. Cancer Inst. 2001, 93, 367-377. [CrossRef] [PubMed]

87. Mortreux, F.; Gabet, A.S.; Wattel, E. Molecular and cellular aspects of HTLV-1 associated leukemogenesis in vivo. Leukemia 2003, 17, 26-38. [CrossRef] [PubMed]

88. Vernin, C.; Thenoz, M.; Pinatel, C.; Gessain, A.; Gout, O.; Delfau-Larue, M.H.; Nazaret, N.; Legras-Lachuer, C.; Wattel, E.; Mortreux, F. HTLV-1 bZIP factor HBZ promotes cell proliferation and genetic instability by activating OncomiRs. Cancer Res. 2014, 74, 6082-6093. [CrossRef] [PubMed] 
89. Satou, Y.; Yasunaga, J.; Zhao, T.; Yoshida, M.; Miyazato, P.; Takai, K.; Shimizu, K.; Ohshima, K.; Green, P.L.; Ohkura, N.; et al. HTLV-1 bZIP factor induces T-cell lymphoma and systemic inflammation in vivo. PLoS Pathog. 2011, 7, e1001274. [CrossRef] [PubMed]

90. Gazon, H.; Lemasson, I.; Polakowski, N.; Cesaire, R.; Matsuoka, M.; Barbeau, B.; Mesnard, J.M.; Peloponese, J.M., Jr. Human T-cell leukemia virus type 1 (HTLV-1) bZIP factor requires cellular transcription factor JunD to upregulate HTLV-1 antisense transcription from the $3^{\prime}$ long terminal repeat. J. Virol. 2012, 86, 9070-9078. [CrossRef] [PubMed]

91. Richardson, J.H.; Edwards, A.J.; Cruickshank, J.K.; Rudge, P.; Dalgleish, A.G. In vivo cellular tropism of human T-cell leukemia virus type 1. J. Virol. 1990, 64, 5682-5687. [PubMed]

92. Karube, K.; Ohshima, K.; Tsuchiya, T.; Yamaguchi, T.; Kawano, R.; Suzumiya, J.; Utsunomiya, A.; Harada, M.; Kikuchi, M. Expression of FoxP3, a key molecule in CD4CD25 regulatory T cells, in adult T-cell leukaemia/lymphoma cells. Br. J. Haematol. 2004, 126, 81-84. [CrossRef] [PubMed]

93. Siegel, R.; Gartenhaus, R.; Kuzel, T. HTLV-I associated leukemia/lymphoma: Epidemiology, biology, and treatment. Cancer Treat. Res. 2001, 104, 75-88. [PubMed]

94. Yamada, Y.; Tomonaga, M. The current status of therapy for adult T-cell leukaemia-lymphoma in Japan. Leuk Lymphoma 2003, 44, 611-618. [CrossRef] [PubMed]

95. Takasaki, Y.; Iwanaga, M.; Imaizumi, Y.; Tawara, M.; Joh, T.; Kohno, T.; Yamada, Y.; Kamihira, S.; Ikeda, S.; Miyazaki, Y.; et al. Long-term study of indolent adult T-cell leukemia-lymphoma. Blood 2010, 115, 4337-4343. [CrossRef] [PubMed]

96. Bazarbachi, A.; Hermine, O. Treatment with a combination of zidovudine and alpha-interferon in naive and pretreated adult T-cell leukemia/lymphoma patients. J. Acquir. Immune Defic. Syndr. Hum. Retrovirol. 1996, 13 (Suppl. 1), S186-S190. [CrossRef] [PubMed]

97. Nasr, R.; el Hajj, H.; Kfoury, Y.; de The, H.; Hermine, O.; Bazarbachi, A. Controversies in targeted therapy of adult T cell leukemia/lymphoma: ON target or OFF target effects? Viruses 2011, 3, 750-769. [CrossRef] [PubMed]

98. Bazarbachi, A.; Suarez, F.; Fields, P.; Hermine, O. How I treat adult T-cell leukemia/lymphoma. Blood 2011, 118, 1736-1745. [CrossRef] [PubMed]

99. Tsukasaki, K.; Ikeda, S.; Murata, K.; Maeda, T.; Atogami, S.; Sohda, H.; Momita, S.; Jubashi, T.; Yamada, Y.; Mine, M.; et al. Characteristics of chemotherapy-induced clinical remission in long survivors with aggressive adult T-cell leukemia/lymphoma. Leuk Res. 1993, 17, 157-166. [CrossRef]

100. Taguchi, H.; Kinoshita, K.I.; Takatsuki, K.; Tomonaga, M.; Araki, K.; Arima, N.; Ikeda, S.; Uozumi, K.; Kohno, H.; Kawano, F.; et al. An intensive chemotherapy of adult T-cell leukemia/lymphoma: CHOP followed by etoposide, vindesine, ranimustine, and mitoxantrone with granulocyte colony-stimulating factor support. J. Acquir. Immune Defic. Syndr. Hum. Retrovirol. 1996, 12, 182-186. [CrossRef] [PubMed]

101. Tobinai, K. Current management of adult T-cell leukemia/lymphoma. Oncology (Williston Park) 2009, 23, 1250-1256. [PubMed]

102. Makiyama, J.; Imaizumi, Y.; Tsushima, H.; Taniguchi, H.; Moriwaki, Y.; Sawayama, Y.; Imanishi, D.; Taguchi, J.; Hata, T.; Tsukasaki, K.; et al. Treatment outcome of elderly patients with aggressive adult T cell leukemia-lymphoma: Nagasaki University Hospital experience. Int. J. Hematol. 2014, 100, 464-472. [CrossRef] [PubMed]

103. Kawano, N.; Yoshida, S.; Kuriyama, T.; Tahara, Y.; Yamashita, K.; Nagahiro, Y.; Kawano, J.; Koketsu, H.; Toyofuku, A.; Manabe, T.; et al. Clinical Features and Treatment Outcomes of 81 Patients with Aggressive Type Adult T-cell Leukemia-lymphoma at a Single Institution over a 7-year Period (2006-2012). Intern. Med. 2015, 54, 1489-1498. [CrossRef] [PubMed]

104. Tsukasaki, K.; Utsunomiya, A.; Fukuda, H.; Shibata, T.; Fukushima, T.; Takatsuka, Y.; Ikeda, S.; Masuda, M.; Nagoshi, H.; Ueda, R.; et al. VCAP-AMP-VECP compared with biweekly CHOP for adult T-cell leukemia-lymphoma: Japan Clinical Oncology Group Study JCOG9801. J. Clin. Oncol. 2007, 25, 5458-5464. [CrossRef] [PubMed]

105. Mercieca, J.; Matutes, E.; Dearden, C.; MacLennan, K.; Catovsky, D. The role of pentostatin in the treatment of T-cell malignancies: Analysis of response rate in 145 patients according to disease subtype. J. Clin. Oncol. 1994, 12, 2588-2593. [PubMed] 
106. Tsukasaki, K.; Tobinai, K.; Shimoyama, M.; Kozuru, M.; Uike, N.; Yamada, Y.; Tomonaga, M.; Araki, K.; Kasai, M.; Takatsuki, K.; et al. Deoxycoformycin-containing combination chemotherapy for adult T-cell leukemia-lymphoma: Japan Clinical Oncology Group Study (JCOG9109). Int. J. Hematol. 2003, 77, 164-170. [CrossRef] [PubMed]

107. Uike, N.; Choi, I.; Tokoro, A.; Goto, T.; Yufu, Y.; Kozuru, M.; Tobinai, K. Adult T-cell leukemia-lymphoma successfully treated with 2-chlorodeoxyadenosine. Intern. Med. 1998, 37, 411-413. [CrossRef] [PubMed]

108. Tobinai, K.; Uike, N.; Saburi, Y.; Chou, T.; Etoh, T.; Masuda, M.; Kawano, F.; Matsuoka, M.; Taguchi, H.; Makino, T.; et al. Phase II study of cladribine (2-chlorodeoxyadenosine) in relapsed or refractory adult T-cell leukemia-lymphoma. Int. J. Hematol. 2003, 77, 512-517. [CrossRef] [PubMed]

109. Makino, T.; Nakahara, K.; Takatsuka, Y.; Shimotakahara, S.; Utsunomiya, A.; Hanada, S.; Tokunaga, M.; Arima, T. [Successful treatment of chemotherapy-resistant adult $\mathrm{T}$ cell leukemia/lymphoma by irinotecan hydrochloride (CPT-11)]. Rinsho Ketsueki 1994, 35, 42-48. [PubMed]

110. Ohno, R.; Masaoka, T.; Shirakawa, S.; Sakamoto, S.; Hirano, M.; Hanada, S.; Yasunaga, K.; Yokomaku, S.; Mitomo, Y.; Nagai, K.; et al. Treatment of adult T-cell leukemia/lymphoma with MST-16, a new oral antitumor drug and a derivative of bis(2,6-dioxopiperazine). The MST-16 Study Group. Cancer 1993, 71, 2217-2221. [CrossRef]

111. Taguchi, T.; Ohta, K.; Hotta, T.; Shirakawa, S.; Masaoka, T.; Kimura, I. [Menogaril (TUT-7) late phase II study for malignant lymphoma, adult T-cell leukemia and lymphoma (ATLL)]. Gan To Kagaku Ryoho 1997, 24, 1263-1271. [PubMed]

112. Tsukasaki, K.; Tomonaga, M. ATRA, NF-kappaB and ATL. Leuk Res. 2001, 25, 407-408. [CrossRef]

113. Toshima, M.; Nagai, T.; Izumi, T.; Tarumoto, T.; Takatoku, M.; Imagawa, S.; Komatsu, N.; Ozawa, K. All-trans-retinoic acid treatment for chemotherapy-resistant acute adult T-cell leukemia. Int. J. Hematol. 2000, 72, 343-345. [PubMed]

114. Hasegawa, H.; Yamada, Y.; Tsukasaki, K.; Mori, N.; Tsuruda, K.; Sasaki, D.; Usui, T.; Osaka, A.; Atogami, S.; Ishikawa, C.; et al. LBH589, a deacetylase inhibitor, induces apoptosis in adult T-cell leukemia/lymphoma cells via activation of a novel RAIDD-caspase-2 pathway. Leukemia 2011, 25, 575-587. [CrossRef] [PubMed]

115. Tsukasaki, K.; Tobinai, K. Clinical Trials and Treatment of ATL. Leuk Res. Treat. 2012, 2012, 101754. [CrossRef] [PubMed]

116. Mori, N.; Matsuda, T.; Tadano, M.; Kinjo, T.; Yamada, Y.; Tsukasaki, K.; Ikeda, S.; Yamasaki, Y.; Tanaka, Y.; Ohta, T.; et al. Apoptosis induced by the histone deacetylase inhibitor FR901228 in human T-cell leukemia virus type 1-infected T-cell lines and primary adult T-cell leukemia cells. J. Virol. 2004, 78, 4582-4590. [CrossRef] [PubMed]

117. Blaheta, R.A.; Cinatl, J., Jr. Anti-tumor mechanisms of valproate: A novel role for an old drug. Med. Res. Rev. 2002, 22, 492-511. [CrossRef] [PubMed]

118. Bezecny, P. Histone deacetylase inhibitors in glioblastoma: Pre-clinical and clinical experience. Med. Oncol. 2014, 31, 985. [CrossRef] [PubMed]

119. Lagneaux, L.; Gillet, N.; Stamatopoulos, B.; Delforge, A.; Dejeneffe, M.; Massy, M.; Meuleman, N.; Kentos, A.; Martiat, P.; Willems, L.; et al. Valproic acid induces apoptosis in chronic lymphocytic leukemia cells through activation of the death receptor pathway and potentiates TRAIL response. Exp. Hematol. 2007, 35, 1527-1537. [CrossRef] [PubMed]

120. Belrose, G.; Gazon, H.; Meniane, J.-C.; Olindo, S.; Mesnard, J.-M.; Peloponese, J.-M.; Cesaire, R. Effects of valproate on Tax and HBZ expression in ex vivo cultured ATL cells. Retrovirology 2014, 11 (Suppl. 1), P39. [CrossRef]

121. Mosley, A.J.; Meekings, K.N.; McCarthy, C.; Shepherd, D.; Cerundolo, V.; Mazitschek, R.; Tanaka, Y.; Taylor, G.P.; Bangham, C.R. Histone deacetylase inhibitors increase virus gene expression but decrease CD8+ cell antiviral function in HTLV-1 infection. Blood 2006, 108, 3801-3807. [CrossRef] [PubMed]

122. Olindo, S.; Belrose, G.; Gillet, N.; Rodriguez, S.; Boxus, M.; Verlaeten, O.; Asquith, B.; Bangham, C.; Signate, A.; Smadja, D.; et al. Safety of long-term treatment of HAM/TSP patients with valproic acid. Blood 2011, 118, 6306-6309. [CrossRef] [PubMed]

123. Berkowitz, J.L.; Janik, J.E.; Stewart, D.M.; Jaffe, E.S.; Stetler-Stevenson, M.; Shih, J.H.; Fleisher, T.A.; Turner, M.; Urquhart, N.E.; Wharfe, G.H.; et al. Safety, efficacy, and pharmacokinetics/pharmacodynamics of daclizumab (anti-CD25) in patients with adult T-cell leukemia/lymphoma. Clin. Immunol. 2014, 155, 176-187. [CrossRef] [PubMed] 
124. Yoshie, O.; Fujisawa, R.; Nakayama, T.; Harasawa, H.; Tago, H.; Izawa, D.; Hieshima, K.; Tatsumi, Y.; Matsushima, K.; Hasegawa, H.; et al. Frequent expression of CCR4 in adult T-cell leukemia and human T-cell leukemia virus type 1-transformed T cells. Blood 2002, 99, 1505-1511. [CrossRef] [PubMed]

125. Yamamoto, K.; Utsunomiya, A.; Tobinai, K.; Tsukasaki, K.; Uike, N.; Uozumi, K.; Yamaguchi, K.; Yamada, Y.; Hanada, S.; Tamura, K.; et al. Phase I study of KW-0761, a defucosylated humanized anti-CCR4 antibody, in relapsed patients with adult T-cell leukemia-lymphoma and peripheral T-cell lymphoma. J. Clin. Oncol. 2010, 28, 1591-1598. [CrossRef] [PubMed]

126. Tsukasaki, K. [Mogamulizumab for the treatment of ATL and PTCL]. Gan To Kagaku Ryoho 2015, 42, 553-557. [PubMed]

127. Ishida, T.; Jo, T.; Takemoto, S.; Suzushima, H.; Uozumi, K.; Yamamoto, K.; Uike, N.; Saburi, Y.; Nosaka, K.; Utsunomiya, A.; et al. Dose-intensified chemotherapy alone or in combination with mogamulizumab in newly diagnosed aggressive adult T-cell leukaemia-lymphoma: A randomized phase II study. Br. J. Haematol. 2015, 169, 672-682. [CrossRef] [PubMed]

128. Kawashima, I.; Sueki, Y.; Yamamoto, T.; Nozaki, Y.; Nakajima, K.; Mitsumori, T.; Kirito, K. Adult T cell leukemia-lymphoma with allo-HSCT after treatment for pulmonary involvement with Mogamulizumab. Rinsho Ketsueki 2015, 56, 210-215. [PubMed]

129. Utsunomiya, A.; Miyazaki, Y.; Takatsuka, Y.; Hanada, S.; Uozumi, K.; Yashiki, S.; Tara, M.; Kawano, F.; Saburi, Y.; Kikuchi, H.; et al. Improved outcome of adult T cell leukemia/lymphoma with allogeneic hematopoietic stem cell transplantation. Bone Marrow Transplant. 2001, 27, 15-20. [CrossRef] [PubMed]

130. Okamura, J.; Uike, N.; Utsunomiya, A.; Tanosaki, R. Allogeneic stem cell transplantation for adult T-cell leukemia/lymphoma. Int. J. Hematol. 2007, 86, 118-125. [CrossRef] [PubMed]

131. Tanosaki, R.; Uike, N.; Utsunomiya, A.; Saburi, Y.; Masuda, M.; Tomonaga, M.; Eto, T.; Hidaka, M.; Harada, M.; Choi, I.; et al. Allogeneic hematopoietic stem cell transplantation using reduced-intensity conditioning for adult $\mathrm{T}$ cell leukemia/lymphoma: Impact of antithymocyte globulin on clinical outcome. Biol. Blood Marrow Transplant. 2008, 14, 702-708. [CrossRef] [PubMed]

132. Hishizawa, M.; Kanda, J.; Utsunomiya, A.; Taniguchi, S.; Eto, T.; Moriuchi, Y.; Tanosaki, R.; Kawano, F.; Miyazaki, Y.; Masuda, M.; et al. Transplantation of allogeneic hematopoietic stem cells for adult T-cell leukemia: A nationwide retrospective study. Blood 2010, 116, 1369-1376. [CrossRef] [PubMed]

133. Kanda, J.; Chiou, L.W.; Szabolcs, P.; Sempowski, G.D.; Rizzieri, D.A.; Long, G.D.; Sullivan, K.M.; Gasparetto, C.; Chute, J.P.; Morris, A.; et al. Immune recovery in adult patients after myeloablative dual umbilical cord blood, matched sibling, and matched unrelated donor hematopoietic cell transplantation. Biol. Blood Marrow Transplant. 2012, 18, 1664.e1-1676.e1. [CrossRef] [PubMed]

134. Bazarbachi, A.; Cwynarski, K.; Boumendil, A.; Finel, H.; Fields, P.; Raj, K.; Nagler, A.; Mohty, M.; Sureda, A.; Dreger, P.; et al. Outcome of patients with HTLV-1-associated adult T-cell leukemia/lymphoma after SCT: A retrospective study by the EBMT LWP. Bone Marrow Transplant. 2014, 49, 1266-1268. [CrossRef] [PubMed]

135. Umino, A.; Nakagawa, M.; Utsunomiya, A.; Tsukasaki, K.; Taira, N.; Katayama, N.; Seto, M. Clonal evolution of adult T-cell leukemia/lymphoma takes place in the lymph nodes. Blood 2011, 117, 5473-5478. [CrossRef] [PubMed]

136. Bangham, C.R.; Cook, L.B.; Melamed, A. HTLV-1 clonality in adult T-cell leukaemia and non-malignant HTLV-1 infection. Semin. Cancer Biol. 2014, 26, 89-98. [CrossRef] [PubMed]

137. Nishioka, C.; Ikezoe, T.; Yang, J.; Komatsu, N.; Bandobashi, K.; Taniguchi, A.; Kuwayama, Y.; Togitani, K.; Koeffler, H.P.; Taguchi, H. Histone deacetylase inhibitors induce growth arrest and apoptosis of HTLV-1-infected T-cells via blockade of signaling by nuclear factor kappaB. Leuk Res. 2008, 32, 287-296. [CrossRef] [PubMed]

(C) 2015 by the authors; licensee MDPI, Basel, Switzerland. This article is an open access article distributed under the terms and conditions of the Creative Commons by Attribution (CC-BY) license (http://creativecommons.org/licenses/by/4.0/). 